REGULAR ARTICLE

\title{
STUDIES ON GENETIC DIVERSITY IN VIGNA MUNGO L. HEPPER IN YMV HOTSPOT
}

\author{
R. KARTHIKEYAN* ${ }^{*}$ R. THIRUMALAI, A. J. NAINU, V. DIVYABHARATHI, \\ R. NARAYANAN, S. MURUGAN
}

Department of Genetics and Plant Breeding, Faculty of Agriculture, Annamalai University, Annamalai Nagar 608 o02, Tamil Nadu, India

\begin{abstract}
The present investigation was conducted to examine the 41 blackgram genotypes along with one check (T-9) to study the genetic diversity. Analysis of variance showed highly significant differences among 41blackgram genotypes for 9 quantitative characters studied. Maximum genotypic and phenotypic variance was recorded for percentage of disease infection, single plant seed yield, and number of pods per plant. Minimum GCV and PCV were recorded for pod length, days to $50 \%$ flowering, number of seeds per pod. High heritability was recorded for percentage of disease infection, single plant seed yield, and number of pods per plant. High heritability coupled with high genetic advance as percent of mean was recorded for percentage of disease infection, single plant seed yield. Genetic diversity estimated in 41 blackgram genotypes using Mahalanobis's $\mathrm{D}^{2}$ statistic. Forty one genotypes were grouped into seven clusters by Tocher method (Mahalanobis Euclidean Distance) cluster analysis. The maximum inter-cluster distance was observed between cluster VI and cluster VII and maximum intra-cluster distance was observed in cluster VI. Cluster VII showed maximum cluster mean value for seed yield per plant. Among all the characters, seed yield per plant and percentage of disease infection contributes maximum.
\end{abstract}

Keywords: Blackgram, Genetic diversity, $\mathrm{D}^{2}$ statistic and cluster analysis

\section{INTRODUCTION}

Blackgram (Vigna mungo L. Hepper) belong to family leguminoseae with chromosome number $2 \mathrm{n}=2 \mathrm{x}=22$. It is a short duration, self-pollinated, diploid grain legume $(2 \mathrm{n}=$ 22) with a small genome size estimated to be $0.56 \mathrm{pg} / 1 \mathrm{C}(574$ Mbp) [1]. India, blackgram contribute 10 per cent of total pulses production [2-4]. Blackgram is a cheap source of dietary protein (24\%). It also contributes $76 \%$ carbohydrate, $3-5 \%$ Fibre, $1.74 \%$ Fat and a major portion of lysine in the vegetarian diet. It is the richest sources of phosphoric acid being 5-10 times richer than other crops. Many factors are responsible for the low productivity of blackgram ranging from plant ideotype to various biotic and abiotic stresses [5]. The selection pressure in case of pulses have been focused on the adaptation to both biotic and abiotic stresses. Pulses have been traditionally cultivated in marginal lands with least inputs [6]. Hence, genetic variability for yield contributing characters were lost during the course of evolution. Yellow Mosaic Virus (YMV) belongs to the genus Begomo virus and is transmitted by the vector whitefly, Bemisia tabaci [7]. An assessment of the genetic diversity of pulses is an important step in a programme to improve crop yield. Hence proper estimate of nature and magnitude of diversity in a crop is essential to understand the extent of variation available for yield and its component traits. Besides, it could be of interest to know the magnitude of variation due to heritable component, which in turn would be a guide for selection for the improvement of a population.

\section{MATERIALS AND METHODS}

The study was conducted at Panmozhi village of Tirunelveli District, Tamil Nadu during summer 2017. Fourty one genotypes of urd bean obtained from various geographical locations. The data were recorded on five randomly selected plants of each replication for all character but in case of days to $50 \%$ flowering the observations were recorded in all plants the rows. Other traits were taken during pre harvest namely, Days to 50\% flowering, Plant height $(\mathrm{cm})$, Number of primary branches per plant, Number of clusters per plant, Number of pods per plant, No. Of seeds per pod, Pod length $(\mathrm{cm})$, percentage of diseases infection, and Seed yield per plant (g). Mean values were computed and data were analyzed for analysis of variance as suggested Fisher [8], Phenotypic coefficient of variation (PCV) and genotypic coefficient of variation (GCV) as per Burton [9], Heritability in broad sense as per Lush [10] and Burton and Devane [11], Genetic advance as per Lush [12] and Johnson et al. [13] and Genetic divergence as per Mahalanobis [14].

Received 21 November 2018; Accepted 30 April 2018

*Corresponding Author

R. Karthikeyan

Department of Genetics and Plant Breeding, Faculty of Agriculture, Annamalai University, Annamalai Nagar 608 oo2, Tamil Nadu, India

Email: agriman2001@yahoo.com

( This article is open access and licensed under the terms of the Creative Commons Attribution License (http://creativecommons.org/licenses/by/4.o/) which permits unrestricted, use, distribution and reproduction in any medium, or format for any purpose, even commercially provided the work is properly cited. Attribution - You must give appropriate credit, provide a link to the license, and indicate if changes were made. 


\section{RESULTS AND DISCUSSION}

The Genetic diversity based on Mahalanobis D2 statistic grouped the 41 genotypes into seven clusters by NonHierarchical Euclidean cluster analysis. Maximum of 22 genotypes were found in Cluster VIII (AUBG 6, AUBG 7, AUBG 8, AUBG10, AUBG11, AUBG13, AUBG14,AUBG15, AUBG16, AUBG17, AUBG19, AUBG20, AUBG22, AUBG24,AUBG27 AUBG29, AUBG30, AUBG31, AUBG32, AUBG34, AUBG36, AUBG37) followed by clusters I with six genotypes (AUBG1, AUBG2, AUBG3, AUBG4, AUBG26, AUBG35) and cluster VII with three genotypes (AUBG5, AUBG28, AUBG40). The cluster II (AUBG18, AUBG33), cluster III (AUBG39, AUBG41), cluster IV (AUBG21, AUBG23) and cluster V (AUBG12, AUBG9) had two genotypes each. The intra-cluster $\left(\mathrm{D}^{2}\right)$ distance ranged from 44.94 to 4302.98 . Cluster II showed minimum intra cluster distance (44.94) and Maximum Intra cluster distance was exhibited by cluster VII (4302.98). Maximum Inter-cluster distance (D2) was found between cluster VI and VII (5575.09). Minimum inter-cluster distance was found between Cluster IV and V (141.23). The results indicated that there is close genetic similarity between the cultivars of blackgram based on the study. The highest contribution of characters in the manifestation of genetic divergence was exhibited by seed yield per plant (53.20\%) followed percentage of disease infection (44.24\%), days to $50 \%$ flowering (0.60\%) suggesting scope for improvement in these characters.

The inter-cluster distance was observed between clusters VI and VII (D2 $=5575.09$ ) indicating high divergence of genotypes included in these two clusters. The lowest intercluster distance was observed between IV and V (D2 $=141.23$ ) indicating that genotypes included in them were closely related. According to Rahman et al., [15], crossing between highly divergent genotypes would produce a broad spectrum of variability. Thus, selection of genotypes from these clusters for a crossing programme will produce desirable transgressive segregants. The genotypes of cluster VII had recorded the highest seed yield per plant-1 while the genotypes of cluster II recorded the lowest seed yield. The genotypes of cluster III had more number of pods per plant-1. Cluster VI included the genotypes having longest pod length. The promising genotypes viz., with high mean values for above traits from divergent clusters were AUBG 30, AUBG3, AUBG 4, AUBG 13, and AUBG 25 may be selected as parents for hybridization programme to develop high yielding blackgram varieties. Among all the characters, grain yield plant-1 (53.20\%) contributed the maximum towards genetic divergence followed by number of seed per pods (0.48\%) and plant height (0.73\%). The maximum contribution of seed yield per plant-1 and number of seed per pods in blackgram were reported by Arivoli et al. [16] which corroborated the results of the present study. Therefore, the genotypes from the clusters having maximum inter-cluster distance can be selected to yield superior segregants $[17,18]$. In the present study, genotypes from cluster I, VII and VIII can be selected for crossing programme to get desirable transgressive segregants. The other genotypes viz., AUBG 3, AUBG 40 and AUBG30 were also found superior for yield and most of the component characters studied. Hence, these genotypes were selected for further improvement through hybridization and selection.

The results indicated that there is close genetic similarity between the cultivars of blackgram based on the study. Whereas the percent contribution of thirteen characters towards total genetic divergence has the highest contribution in the manifestation of genetic divergence was exhibited by seed yield per plant (53.20\%) followed by percentage of disease infection (44.14\%).

On the basis of results of the experiment it can be conclude that, the genotypes AUBG-3, followed by AUBG-40 were identified as the genotypes for high seed yield at the hot spot region. The present investigation registered that high seed yield along with high genetic advance as \% of mean should be given top priority for effective selection. The present investigation further revealed that Cluster VIII and Cluster $\mathrm{V}$ were the most divergent clusters. Therefore, genotypes present in these clusters are suggested to provide broad spectrum variability in segregating generations. Our results are in agreement with previous reports [19-22].

It is observed that no cluster contained at least one genotype with all the desirable traits which ruled out the possibility of selecting directly one genotype for immediate use therefore hybridization between the selected genotype from divergent clusters is essential to judiciously combine all the targeted traits. The genotype from the cluster having high mean value may be used as parent in future hybridization programme.

Table 1: Analysis of variance from 9 different quantitative characters in 41 genotypes of blackgram

\begin{tabular}{|c|c|c|c|c|}
\hline \multirow[t]{2}{*}{ S. No. } & \multirow[t]{2}{*}{ Character } & \multicolumn{3}{|c|}{ Mean sum of square } \\
\hline & & Replication $\mathbf{d f}=\mathbf{2}$ & Treatment df $=40$ & Error df $=80$ \\
\hline 1 & Days to $50 \%$ flowering & 40.92 & $15.69^{* *}$ & 0.59 \\
\hline 2 & Plant height $(\mathrm{cm})$ & 37.66 & $138.45^{* *}$ & 7.02 \\
\hline 3 & Number of primary branches & 5.09 & $2.24^{* *}$ & 1.31 \\
\hline 4 & Number of clusters per plant & 11.7 & $6.91^{* *}$ & 2.77 \\
\hline 5 & Number of pods per plant & 44.47 & $210.51^{* *}$ & 3.83 \\
\hline 6 & Pod length $(\mathrm{cm})$ & 0.28 & $0.26 * *$ & 0.17 \\
\hline 7 & Number of seeds per pod & 0.13 & $1.06 * *$ & 0.08 \\
\hline 8 & $\%$ of disease infection & 76.77 & $1013.44^{* *}$ & 0.34 \\
\hline 9 & Single plant seed yield (g) & 4.03 & $0.34^{* *}$ & 1.65 \\
\hline
\end{tabular}


Table 2: Magnitude of variability and estimates of heritability and genetic advance for various characters in 41 blackgram genotypes

\begin{tabular}{lllllll}
\hline S. No. & Characters & GCV (\%) & PCV (\%) & ECV (\%) & Hertibility & $\begin{array}{l}\text { GA as percent of } \\
\text { mean }\end{array}$ \\
\hline 1. & Days to 50 \% flowering & 6.07 & 6.42 & 2.09 & $89 \%$ & 11.82 \\
2. & Plant height (cm) & 18.55 & 19.98 & 7.42 & $86 \%$ & 35.48 \\
3. & Number of primary branches & 9.09 & 20.79 & 18.69 & $19 \%$ & 8.20 \\
4. & Number of clusters per plant & 13.74 & 23.85 & 19.49 & $33 \%$ & 16.32 \\
5. & Number of pods per plant & 28.19 & 28.97 & 6.65 & $94 \%$ & 56.53 \\
6. & Pod length (cm) & 3.80 & 9.68 & 8.90 & $15 \%$ & 3.07 \\
7. & Number of seeds per pod & 8.40 & 939 & 4.19 & $80 \%$ & 15.49 \\
8. & \% of disease infection & 56.36 & 56.39 & 1.78 & $99 \%$ & 49.05 \\
9. & Single plant seed yield (g) & 34.00 & 34.57 & 6.25 & $96 \%$ & 45.89 \\
\hline
\end{tabular}

Table 3: Distribution of 41 blackgram genotypes into different clusters

\begin{tabular}{|c|c|c|c|c|c|c|c|c|}
\hline Clusters & $\begin{array}{l}\text { Number of } \\
\text { genotypes }\end{array}$ & \multicolumn{7}{|c|}{ Name of genotypes } \\
\hline I & 6 & \multicolumn{7}{|c|}{ AUBG 1,AUBG 2,AUBU 3,AUBG 4,AUBG 26,AUBG 35} \\
\hline II & 2 & \multicolumn{7}{|c|}{ AUBG 18,AUBG 33} \\
\hline III & 2 & \multicolumn{7}{|c|}{ AUBG 39,AUBG 41} \\
\hline IV & 2 & \multicolumn{7}{|c|}{ AUBG 21,AUBG 23} \\
\hline $\mathrm{V}$ & 2 & \multicolumn{7}{|c|}{ AUBG 9,AUBG 12} \\
\hline VI & 2 & \multicolumn{7}{|c|}{ AUBG 25,AUBG 38} \\
\hline VII & 3 & \multicolumn{7}{|c|}{ AUBG 5,AUBG 28, AUBG 40} \\
\hline VIII & 22 & \multicolumn{7}{|c|}{$\begin{array}{l}\text { AUBG 6,AUBG 7,AUBG 8,AUBG 11,AUBG 13,AUBG 14, AUBG 15,AUBG 16,AUBG 17,AUBG 19, } \\
\text { AUBG 20,AUBG 22,AUBG 24,AUBG 27,AUBG 29,AUBG 30,AUBG 31,AUBG 32,AUBG34,AUBG } \\
\text { 36,AUBG } 37\end{array}$} \\
\hline \multicolumn{9}{|c|}{$\begin{array}{c}\text { Table 4: Inter-cluster and intra-cluster (diagonal) average of } \mathrm{D}^{2} \text { (parenthesis) and D values for } 41 \text { blackgram } \\
\text { genotypes }\end{array}$} \\
\hline Cluster & $\mathbf{I}$ & II & III & IV & $\mathbf{V}$ & VI & VII & VIII \\
\hline I & $\begin{array}{l}35.055 \\
(1228.882)\end{array}$ & $\begin{array}{l}24.753 \\
(612.694)\end{array}$ & $\begin{array}{l}35.023 \\
(1226.638)\end{array}$ & $\begin{array}{l}28.717 \\
(824.684)\end{array}$ & $\begin{array}{l}34.330 \\
(1178.549)\end{array}$ & $\begin{array}{l}25.055 \\
(627.729)\end{array}$ & $\begin{array}{l}70.575 \\
(4980.806)\end{array}$ & $\begin{array}{l}48.061 \\
(2309.896)\end{array}$ \\
\hline II & & $\begin{array}{l}6.704 \\
(44.946)\end{array}$ & $\begin{array}{l}25.084 \\
(629.211)\end{array}$ & $\begin{array}{l}18.824 \\
(354.334)\end{array}$ & $\begin{array}{l}26.122 \\
(682.357)\end{array}$ & $\begin{array}{l}16.338 \\
(266.922)\end{array}$ & $\begin{array}{l}66.850 \\
(4468.932)\end{array}$ & $\begin{array}{l}42.675 \\
(1821.156)\end{array}$ \\
\hline III & & & $\begin{array}{l}6.901 \\
(47.627)\end{array}$ & $\begin{array}{l}17.269 \\
(298.216)\end{array}$ & $\begin{array}{l}13.282 \\
(176.418)\end{array}$ & $\begin{array}{l}36.099 \\
(1303.138)\end{array}$ & $\begin{array}{l}49.418 \\
(2442.104)\end{array}$ & $\begin{array}{l}42.506 \\
(1806.798)\end{array}$ \\
\hline IV & & & & $\begin{array}{l}7.494 \\
(56.162)\end{array}$ & $\begin{array}{l}11.884 \\
(141.230)\end{array}$ & $\begin{array}{l}26.748 \\
(715.474)\end{array}$ & $\begin{array}{l}56.104 \\
(3147.659)\end{array}$ & $\begin{array}{l}41.034 \\
(1683.823)\end{array}$ \\
\hline V & & & & & $\begin{array}{l}7.704 \\
(59.348)\end{array}$ & $\begin{array}{l}35.028 \\
(1226.946)\end{array}$ & $\begin{array}{l}50.168 \\
(2516.878)\end{array}$ & $\begin{array}{l}42.309 \\
(1790.015)\end{array}$ \\
\hline VI & & & & & & $\begin{array}{l}8.282 \\
(68.598)\end{array}$ & $\begin{array}{l}74.667 \\
(5575.094)\end{array}$ & $\begin{array}{l}46.479 \\
(2160.256)\end{array}$ \\
\hline VII & & & & & & & $\begin{array}{l}65.597 \\
(4302.985)\end{array}$ & $\begin{array}{l}69.286 \\
(4800.584)\end{array}$ \\
\hline VIII & & & & & & & & $\begin{array}{l}57.858 \\
(3347.509)\end{array}$ \\
\hline
\end{tabular}

Table 5: Cluster means of 41 blackgram genotypes for various characters

\begin{tabular}{|c|c|c|c|c|c|c|c|c|c|}
\hline Clusters & $\begin{array}{l}\text { Days to } \\
50 \% \\
\text { flowering }\end{array}$ & $\begin{array}{l}\text { Plant } \\
\text { height } \\
\text { (cm) }\end{array}$ & $\begin{array}{l}\text { Number } \\
\text { of } \\
\text { primary } \\
\text { branches }\end{array}$ & $\begin{array}{l}\text { Number } \\
\text { of } \\
\text { clusters } \\
\text { per } \\
\text { plant }\end{array}$ & $\begin{array}{l}\text { Number } \\
\text { of pods } \\
\text { per } \\
\text { plant }\end{array}$ & $\begin{array}{l}\text { Pod } \\
\text { length } \\
\text { (cm) }\end{array}$ & $\begin{array}{l}\text { Number } \\
\text { of seeds } \\
\text { per pod }\end{array}$ & $\begin{array}{l}\text { \% of } \\
\text { disease } \\
\text { infection }\end{array}$ & $\begin{array}{l}\text { Single } \\
\text { plant } \\
\text { seed } \\
\text { yield } \\
\text { (g) }\end{array}$ \\
\hline I & 37.325 & 37.128 & 5.906 & 8.167 & 29.239 & 4.740 & 6.800 & 25.389 & 22.556 \\
\hline II & 36.712 & 39.350 & 6.867 & 10.083 & 31.800 & 4.835 & 6.300 & 25.175 & 12.077 \\
\hline III & 39.178 & 31.483 & 5.983 & 9.283 & 38.933 & 4.632 & 7.100 & 37.175 & $15.75^{2}$ \\
\hline IV & 35.652 & 39.383 & 6.517 & 7.183 & 17.033 & 5.092 & 7.450 & 34.252 & 18.682 \\
\hline V & $37 \cdot 345$ & 30.083 & 5.667 & 10.367 & 18.017 & 4.755 & 6.517 & 38.868 & 19.360 \\
\hline VI & 35.520 & 30.483 & 6.717 & 7.417 & 29.700 & $4 \cdot 347$ & 6.900 & 20.633 & 24.028 \\
\hline VII & 37.276 & 40.122 & 6.422 & 10.756 & 37.522 & 4.699 & 7.100 & 54.041 & 27.821 \\
\hline VIII & 36.803 & 35.365 & 6.039 & 8.198 & $29.45^{2}$ & 4.659 & 6.776 & 32.277 & 19.940 \\
\hline
\end{tabular}


Table 6: Contribution of 9 different characters to genetic divergence

\begin{tabular}{lll}
\hline S. No. & Characters & Contribution (\%) \\
\hline 1 & Days to 50\%Flowering & 0.609 \\
2 & Plant Height & 0.731 \\
3 & Number of Primary Branches & 0.112 \\
4 & Number of Clusters per Plant & 0.097 \\
5 & Number of Pods per Plant & 0.487 \\
6 & Pod length & 0.122 \\
7 & Number of Seeds per Pod & 0.487 \\
8 & Percentage of disease infection & 44.146 \\
9 & Single plant seed yield & 53.204 \\
\hline
\end{tabular}

\section{REFERENCES}

1. Chaitieng B, Kaga A, Tomooka N, Isemura T, Kuroda Y, Vaughan DA. Development of a black gram [Vigna mungo (L.) Hepper] linkage map and its comparison with an azuki bean [Vigna angularis (Willd.) Ohwi and Ohashi] linkage map. Theoretical and Applied Genetics. 2006;113:1261-9.

2. Joshi PK, Saxena R. A profile of pulses production in India: Facts, trends and opportunities. Indian Journal of Agricultural Economics. 2002;57:326.

3. Reddy AA. Consumption pattern, trade and production potential of pulses. Economic and political weekly. 2004:4854-60.

4. Bishnoi A, Gupta P, Meghawal DR, Lal GM. Evaluation of genetic variability and heritability in blackgram (Vigna mungo (L.) Hepper) genotypes. Journal of Pharmacognosy and Phytochemistry. 2017;6:493-6.

5. Palaniappan J. Validation of molecular markers linked with yellow mosaic disease resistance in blackgram Vigna mungo (L.) Hepper. Legume Genomics and Genetics. 2014 May 20;5.

6. Caraveli H. A comparative analysis on intensification and extensification in Mediterranean agriculture: dilemmas for LFAs policy. Journal of Rural Studies. 2000;16:231-42.

7. Qazi J, Ilyas M, Mansoor S, Briddon RW. Legume yellow mosaic viruses: genetically isolated begomoviruses. Molecular plant pathology. 2007;8:343-8.

8. Fisher, R. A. (1936) Statistical tables for biological, agricultural and mendelian inheritance. France Royal Society of Edinburgh, 52:399-43

9. Burton, G. W. and De Vane, E. M. (1953) Estimating heritability in tall fesses from replicated cloned material. Journal of Agronomy, 45: 474-481.

10. Lush JL. Intra-sire correlations or regressions of offspring on dam as a method of estimating heritability of characteristics. Proceedings of the American Society of Animal Nutrition. 1940;1940:293-301.
11. Burton GW, Devane EH. Estimating heritability in tall fescue (Festuca arundinacea) from replicated clonal material 1. Agronomy Journal. 1953;45:478-81.

12. Lush. J. L. (1949). Proc. VlJ. Int. Congo Genet. Suppl. Heriditas, 36:356-375

13. Johnson, H. W., Robinson, H. F. and Comstock. R. E. (1955) Genotypic and Phenotypic Correlations in Soybean and their implications in selection. Agronomy journal, 47:477-438.

14. Mahalanobis PC (1936) On the generalised distance in statistics. Proceedings of the National Institute of Sciences of India 2:49-55.

15. Rahman M, Hussain D, Zafar Y. Estimation of genetic divergence among elite cotton cultivars-genotypes by DNA fingerprinting technology. Crop Science. 2002;42:2137-44.

16. Arivoli S, Hema M, Prasath PM. Adsorption of malachite green onto carbon prepared from borassus bark. The Arabian Journal for Science and Engineering. 2009;34(2a).

17. Mishra.,2003. Genetic divergence and characters association in micro mutants of mung bean variety sujatha Indian Journal of pulses research., 19:184-186

18. Chaturvedi HP, Maurya DM. Genetic divergence analysis in rice (Oryza sativa L.). Adv. Plant Sci. 2005;18:349-53.

19. Appalaswamy, A. and Reddy (2004) Genetic divergence and heterosis studies of mungbean (Vigna radiata L. Wilczek). Legume Research, 21:115-118.

20. Deepalakshmi, A. J. and Anandakumar, C. K. (2004) Creation of genetic variability for different polygenic traits in blackgram (Vigna mungo L. Hepper) through induced mutagenesis. Legume Research, 3:188-192.

21. Singh, K. N. (1980) Path analysis in linseed under sodic soil condition. Indian journal genetics and plant breeding, 40:385-387.

22. Nene Y. L., 1972, A survey of the viral disease of pulse crop in uttar pradesh, G. B. Pant University of Agriculture and technology, Pantnagar, Res. Bull., 4:191 